\title{
BIOMETRIC TECHNOLOGIES AND THE PROSPECT OF SUSTAINABLE DEMOCRACY IN AFRICA
}

\section{Harrison Adewale Idowu}

Harrison Adewale Idowu is an assistant lecturer in the Department of Public Administration and Political Science, Adekunle Ajasin University, AkungbaAkoko, and a PhD candidate in the Department of Political Science, Obafemi Awolowo University, Ile-Ife, Nigeria

\begin{abstract}
The paper interrogates the prospect of attaining sustainable democracy in Africa using biometric technology (BT) for elections. Technology has become relevant in virtually every aspect of human endeavour, including election management and democratic development. In Africa, BT has also been deployed to improve the quality of elections and democracy. Using document analysis and review of relevant literature, findings indicate that to a large extent, BT is charting the path for sustainable democracy in Africa. However, the deployment of BT for African elections still faces serious challenges such as its high cost, inability to address some forms of electoral fraud, and lack of technical know-how. The paper concludes that the cultivation of political will to improve the quality of elections is important in order to address the current challenges of using BT in African elections and increase the prospect of attaining sustainable democracy.
\end{abstract}

Keywords: Biometric technology, democracy, sustainable democracy, sustainable development, African elections

\section{INTRODUCTION}

Election administration, often regarded as the life blood of democracy (Idowu 2017), has often been problematic and controversial in Africa (Arnold 2014), and fraught with irregularities (Idowu 2018; Idowu \& Mimiko 2020a), thereby undermining the prospects for sustainable democracy on the continent. Thus, the quest to improve the quality of elections and attain sustainable democracy 
had led to the adoption of innovations in biometric technology by several African countries. This is important because as Mumford (1964, p.7) admonishes, 'I wish... to persuade those who are concerned with maintaining democratic institutions to see that their constructive efforts must include technology itself'. While Zambia has adopted electronic voting (e-voting), Ghana, Nigeria, Gambia, Kenya and Côte d'Ivoire, among others, have deployed one form of BT or another for election administration, with the primary aim to curb the numerous challenges in their electoral systems.

Beyond the aforementioned countries, there is increased deployment across Africa of technological innovations in election administration for the purpose of sustainable democracy. The Maendeleo Policy Forum (2016, p.1) avers that technologies have been adopted by most African countries to improve 'biometric voter registration, database management, verify voter eligibility, automate recording and counting of votes cast and transmission of election results'. Among the various technologies deployed for elections in Africa, Osei-Offul (2017) posits that BT is taking the lead in the registration, authentication and identification of voters. More than 25 countries on the continent have deployed BT in election administration, while African countries constitute more than half the countries using BT worldwide (Genkey 2017). The critical question which remains, however, is the extent to which BT has been able to resolve the numerous electoral challenges confronting Africa and how much BT has increased the prospect of attaining sustainable democracy on the continent. Our argument is that quality elections increase the prospect of sustainable democracy. Hence, Piccolino's (2014) assertion that a quality electoral voter register/list impacts on the quality of elections and by extension, democracy.

Nevertheless, while electoral technological innovations have been applauded as improving electoral integrity across the board (Osei-Offul 2017), they have also been viewed differently as not being a quick fix for problematic elections and they could be used to further manipulate the process (Russell \& Zamfir 2018). While much attention has been directed towards studies on technological innovations in fields like the biomedical and chemical industries and sciencerelated research, only scanty research exists on technological innovations with respect to the information system (IS) field, especially as it concerns Africa (Iizuka 2013), electoral improvement and sustainable democracy. With different ways in which technological innovations have advanced communications, health care, and banking, among others, the question then is what role can it play or is it playing in strengthening elections and democracy in Africa? This is the thrust of this paper.

The paper is structured as follows: the next section conceptualises sustainable democracy and BT. The subsequent section three provides the theoretical 
framework upon which the paper is built, while section four explores various electoral biometric technological innovations. Section five maps the deployment of BT for elections in Africa, while section six examines the prospect of attaining sustainable democracy in Africa through BT. The final two sections explore the challenges and limitations of deploying BT for African democratic elections, and concluding remarks respectively.

\section{CONCEPTUALISING BIOMETRIC TECHNOLOGY AND SUSTAINABLE DEMOCRACY}

Biometric technology refers to the type of technology designed to identify unique individual identity using fingerprints, speech, gait, odour, and DNA, among others. It is the 'verification and identification of humans using their possessed biological (anatomical, physiological and behavioural) properties... [it is] the automated use of physiological or behavioural characteristics to determine or verify an individual's identity' (Wang \& Yanushkevich 2007, p. 226). BTs are those automatic technologies designed for the purpose of identification, to measure and analyse biological and anthropological characteristics such as fingerprints, eye retinas/irises, voices, faces, and hand measurement. They operate via the generation of computer models of the physical and behavioural characteristics of individuals in order to reliably identify such individuals (Wang \& Yanushkevich 2007). BT adopts patterns of recognition algorithms which enable it to identify unique individuals. They operate with biometrics, that is any human physiological or behavioural characteristics which possess general biometric properties (Bolle et al. 2004). Bolle et al. (2004) and Yakubu (2017) further highlight the various biometric properties as follows:

- Universality: implies that every individual has the characteristics being measured;

- Uniqueness: suggests that no two individuals can be exactly the same in terms of the characteristics being measured;

- Permanence: it is invariant with time;

- Collectability: it can be subjected to quantitative measurement;

- Reliability/Performance: it must be safe and its performance level must be satisfactory;

- Acceptability: it must be socially acceptable and tolerable; and

- Circumvention: it may not be easily manipulated.

The figure below presents the diagrammatical representation of biometric properties: 


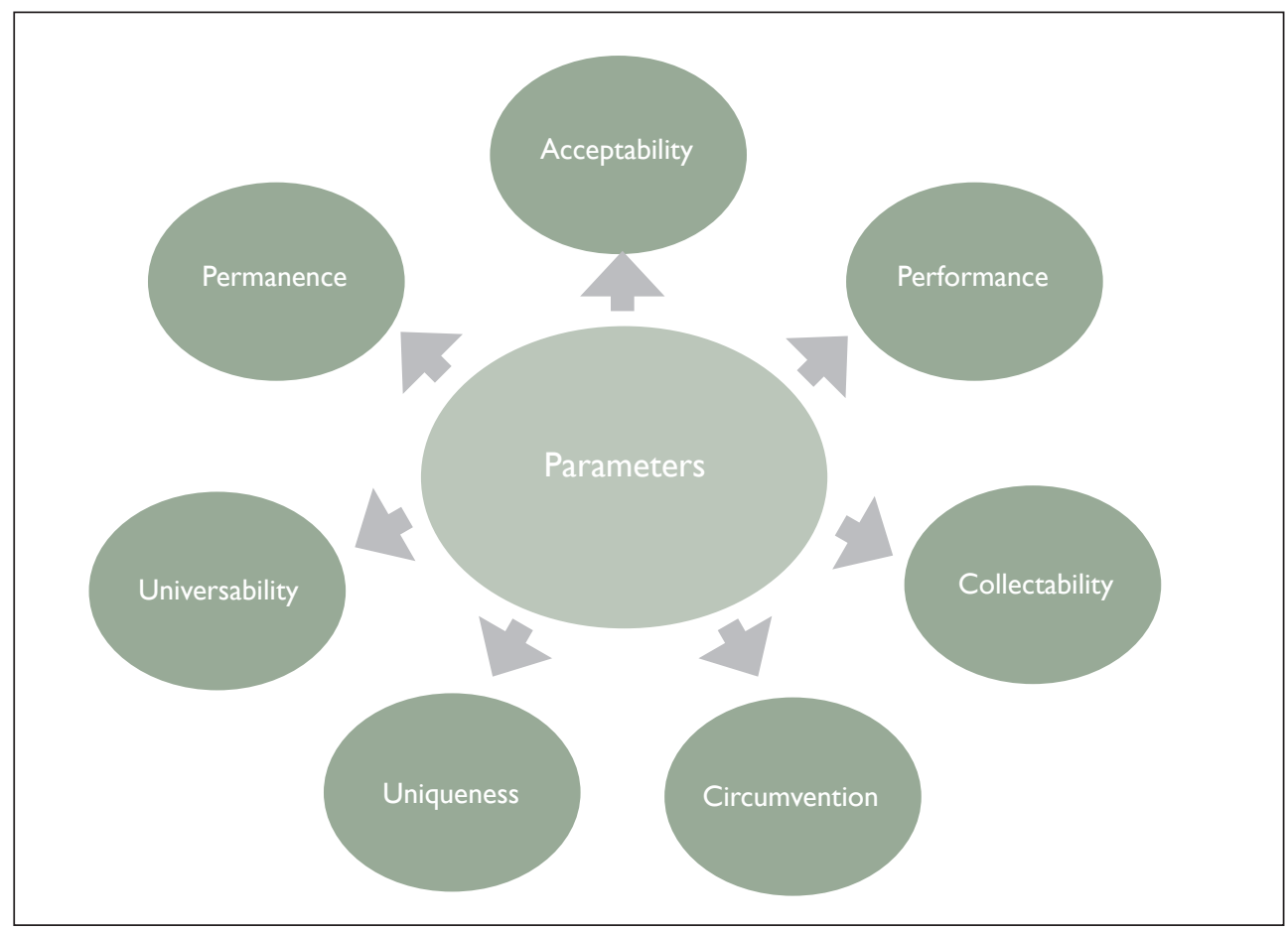

\section{Figure 1: Biometric properties}

Source: Yakubu (2017, p.4)

Lorimer and Lechner (1995) define sustainable democracy as the continued reasonably high and stable level of democracy. It is a level of democracy which has become stable over time and in which democratic institutions such as the election management bodies (EMBs), legislature and judiciary are reasonably efficient. It is the level of democracy which should last well into the future without experiencing collapse or retrogression. Elections remain one of the most prominent tools for gauging democratic progress. As such, a democracy where elections are credible, transparent, free, fair, periodic and largely inclusive, participatory and competitive, and where the EMB is efficient, independent and impartial, could be said to have attained sustainability. Sustainable democracy implies a democracy attained and practised today, which does not pose a threat to tomorrow's democracy.

\section{THEORETICAL FRAMEWORK}

The paper adopts the e-democracy model of analysis to explain the link between $\mathrm{BT}$ and the prospect of attaining sustainable democracy, and the general role 
of technological innovations in improving electoral integrity and advancing democracies. Moynihan (2004, pp. 515-528) presents the basic argument of e-democracy thus: 'the declining rate of trust in government can be reversed through the use of technology either indirectly through greater citizen satisfaction with more convenient services or directly through enhancing civic participation in the public sphere'. The theory posits that when technology aids civic participation (such as elections/voting), then it is referred to as 'digital democracy' or 'e-civics' or 'e-democracy' (Moynihan 2004; Robertson 2006). No doubt there are possibilities of technology failure, especially when it is massively deployed for elections, when the choices of vendor and the type of technology to be deployed in an election must be taken into due consideration. Following this, Olurode (2017) avers that while vendors are guided by the quest for profit maximization, election managers (EMBs) must be guided by transparency, credibility and the quest for advancing and stabilising democracy. By so doing, the prospect of sustainable democracy is high.

E-democracy ensures that electoral quality is improved and this has a profound effect on democracy on the continent. As argued by Olurode (2017, p. 802), 'without doubt, the culture of digital democracy is spreading in Africa and it is triggering profound changes in its democratisation processes'. The profound and critical role of technology in reducing electoral bloodshed and violence has also been stressed (Olurode 2017); a feat which has had an immense impact on democratisation and democratic institutions (such as EMBs) on the continent. Better citizen participation enhances electoral credibility and transparency, thereby advancing democratic growth. This quest for better citizen participation in Africa had prompted the heavy deployment of BT for most elections. Technology has improved the secrecy of balloting, built stronger electoral institutions (EMBs, civil societies, independent observers and the media), improved electorates' autonomy and confidence, increased the prospect of votes to count, and reduced electoral impunity/violence (Olurode 2017). BT has been able to produce cleaner and more accurate voter registers, and thereby reduced electoral manipulations. All of these point to the essential role of technology in the quest for sustainable democracy in Africa. The theory of e-democracy is useful to analyse the role of technological innovation like the BT in achieving sustainable democracy in Africa.

\section{RESEARCH METHODS}

The paper adopts the explanatory research design. It relies on secondary data using document analysis and reviews of relevant literature such as text books, journal articles, magazine publications, official documents and gazettes, 
newspaper articles, and the Internet. Data so collected from these sources were analysed using explanatory and content analysis.

\section{ELECTORAL BIOMETRIC TECHNOLOGICAL INNOVATIONS}

There are several biometric technological innovations deployed globally for the purpose of elections. Wolf (2017, pp. 21-22) presents the various forms of BT deployed for elections. These forms are presented and discussed as follows:

1. Biometric Voter Registration (BVR): This is used for voters' registration, using any of the various biometric characteristics. The biometric voter registration produces a voter register containing biometric data such as fingerprints, iris scans, and facial image, including a voter's biographic information. The various biometric data which could be captured during biometric voter registration include fingerprints, facial images, signatures and iris scans (Wolf 2017, pp. 21-22). Others may include DNA matching, vein patterns recognition and voice recognition. While face, fingerprints, hand, iris and DNA biometrics are physiological features, keystroke, signature and voice biometrics are behavioural features (Gemalto 2019). The figure below presents a diagrammatical representation of the various biometric characteristics.
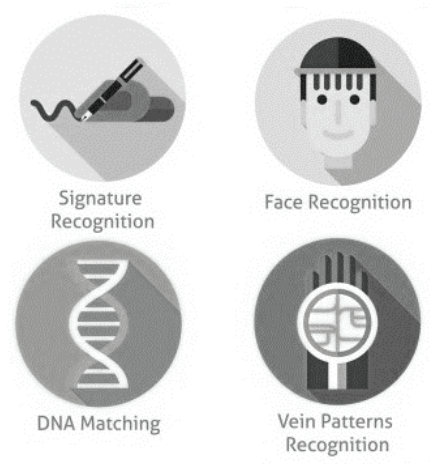
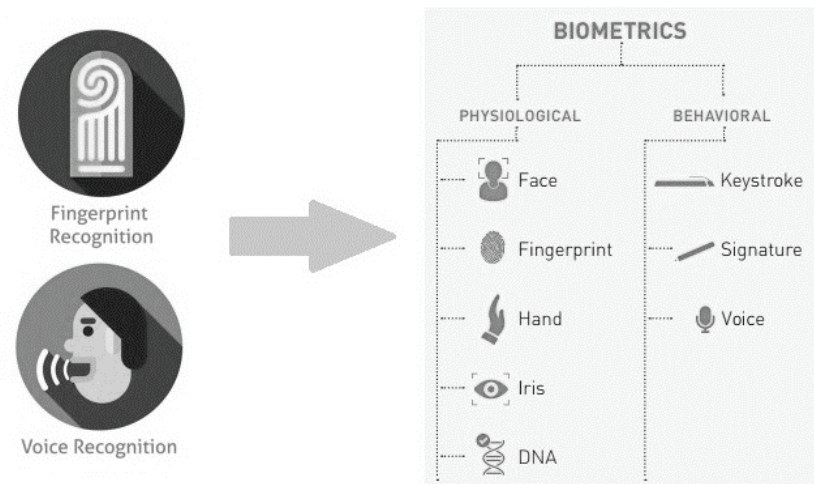

Figure 2: Biometric Characteristics for Biometric Voter Registration 
2. Biometric Voter ID Cards: Following the biometric registration, some of the voters' identification could be electronically printed on voter ID cards. This will usually, but not in all cases, consist of the voter's photograph, fingerprints and signature. An example is the permanent voter's card (PVC).

3. Biometric De-duplication: Biometric de-duplication is a form of BT which allows for the detection and removal of multiple cases of registration from the voter register. This is done by the identification and matching of various biometric characteristics like the fingerprints, facial images and irises of registered voters on the register of voters. At the detection of similar biometric characters, removals are made, while retaining only one name on the register.

4. Biometric Voter Verification (BVV): This is a BT often deployed on election day to identify and verify eligible registered voters. The technology also uses biometric details of voters as captured during registration to verify whether they are the actual voters and that they are not impersonations. This technology is used to prevent impersonation and multiple voting. BVV is usually carried out via the use of devices such as electronic poll books which have the ability to capture voters' fingerprints and compare them with those already stored on the system during the biometric registration stage.

\section{MAPPING THE DEPOLOYMENT OF ELECTORAL BIOMETRIC TECHNOLOGY IN AFRICA}

The deployment of BTs in African elections will doubtless continue to increase. While countries such as Zambia and Democratic Republic of the Congo (DRC) have gone as far as adopting e-voting for elections, BT remains the most widely used for the registration, authentication and identification of voters, with over 25 countries involved (Osei-Offul 2017). African countries also constitute more than half of all the countries using BT globally (Genkey 2017). Furthermore, in 2017 Somaliland became the first country in Africa and the first in the world to make use of iris recognition-based biometric voting system. Africa's strides in the deployment of BTs for elections has the aim of addressing the numerous challenges with voter registration and verification on the continent, and by so doing of improving the electoral process. This thus warrants the attention so accorded BT in African elections.

BT has been seen and projected as the ideal means through which African states can improve their electoral process and allow for secure identification (Gelb \& Clark 2013; Gelb \& Decker 2012). As observed by Gelb and Clark (2013), the 
market for BT in Africa had improved between 2005 and 2010. This resulted in a tremendous increase in the BT market from 87.7 million US dollars in 2005 to 415.8 million US dollars in 2010, amounting to $37 \%$ growth per year - the highest records globally. Between 2005 and 2006, DRC became the first African country to deploy BT for voters' registration. Senegal, Nigeria and Togo followed in 2007; while in 2008, Angola, Mozambique and Rwanda deployed BT in their electoral processes. In 2010, Côte d'Ivoire, Guinea and Somaliland were the next to deploy electoral BT, while Zambia, Uganda, Gambia, Cape Verde and Benin Republic utilised BT in their elections in 2011. Electoral BTs were deployed by Ghana and Sierra Leone in 2012; and in 2013, Burkina Faso, Cameroon, Gabon, Kenya, Mali and Swaziland deployed electoral BT. Some of the latecomers in the use of BT for elections include Namibia, which deployed BT in 2014, and Comoros which deployed BT in 2015. Also, in 2015, 2016 and 2017, Tanzania, Niger Republic and Zimbabwe respectively deployed electoral BTs for the first time. The various BTs have ranged from the direct data capture machines, smart card readers (SCR), permanent voter cards (PVC), biometric voter registration system (BVR) and electronic voter identification system (EVID). Table 1 below presents the tracking for first-time deployment of BT among some African countries.

\section{Table 1: Timelines of BT Deployment in African Elections}

\begin{tabular}{|l|c|c|}
\hline Country & $\begin{array}{c}\text { Adoption of } \\
\text { biometrics in } \\
\text { elections }\end{array}$ & $\begin{array}{c}\text { First elections held with } \\
\text { biometric register }\end{array}$ \\
\hline Angola & Yes & 2008 \\
\hline Benin & Yes & 2011 \\
\hline Botswana & No & 2013 \\
\hline Burkina Faso & Yes & \\
\hline Burundi & No & 2013 \\
\hline Cameroon & Yes & 2011 \\
\hline Cape Verde & Yes & \\
\hline Central African Republic & No & 2016 \\
\hline Chad & Yes & 2015 \\
\hline Comoros & Yes & 2010 \\
\hline Côte d'Ivoire & Yes & 2011 \\
\hline Democratic Republic of Congo & Yes & 2015 \\
\hline Djibouti & No & \\
\hline Equatorial Guinea & Yes & \\
\hline
\end{tabular}




\begin{tabular}{|c|c|c|}
\hline Eritrea & No & \\
\hline Ethiopia & No & \\
\hline Gabon & Yes & 2013 \\
\hline Gambia & Yes & 2011 \\
\hline Ghana & Yes & 2012 \\
\hline Guinea & Yes & 2010 \\
\hline Guinea-Bissau & No & \\
\hline Kenya & Yes & 2013 \\
\hline Lesotho & Yes & 2002 \\
\hline Liberia & Yes & 2017 \\
\hline Madagascar & No & \\
\hline Malawi & Yes & 2019 \\
\hline Mali & Yes & 2013 \\
\hline Mauritania & Yes & 2010 \\
\hline Mauritius & No & \\
\hline Morocco & Yes & 2016 \\
\hline Mozambique & Yes & 2008 \\
\hline Namibia & Yes & 2014 \\
\hline Niger & Yes & 2016 \\
\hline Nigeria & Yes & 2007 \\
\hline Republic of Congo & No & \\
\hline Rwanda & Yes & 2008 \\
\hline Senegal & Yes & 2007 \\
\hline Sierra Leone & Yes & 2012 \\
\hline Somaliland & Yes & 2010 \\
\hline Somalia & No & \\
\hline South Africa & No & \\
\hline South Sudan & No & \\
\hline Swaziland & Yes & 2013 \\
\hline Togo & Yes & 2007 \\
\hline Tanzania & Yes & 2015 \\
\hline Uganda & Yes & 2011 \\
\hline Zambia & Yes & 2011 \\
\hline Zimbabwe & Yes & 2017 \\
\hline
\end{tabular}

Source: Adapted from Piccolino (2016, p.501) and updated by the author 


\section{BIOMETRIC TECHNOLOGIES IN AFRICAN ELECTIONS AND SUSTAINABLE DEMOCRACY IN AFRICA}

As the e-democracy model of analysis explains the significant role BT plays in elections and democracy, there is no gainsaying the fact that the various BTs that have been deployed across the African continent have gone a long way to improve electoral credibility and transparency. By so doing, they have advanced and placed the continent's democracy on the path of sustainability. The problems that BT can tackle in elections are those that most routinely and seriously affect African elections. For example, BT is of immense utility in helping to ensure that only qualified voters vote and in producing accurate voting rolls, as is indicated below. These are prominent and serious challenges which have routinely and adversely impacted African elections over the years.

One important aspect in which BT has helped achieve improvements in African elections, is the refinement and upgrading of voter registers. The list of registered voters has long been regarded as a necessary precondition for free and fair elections and sustainable democracy (Piccolino 2014). This is also because the conduct of democratic elections relies on reliable voter registers. An improved voter register impacts positively on electoral integrity, and by extension, the quest for sustainable democracy. Thus, according to the ACE Electoral Knowledge Network (n.d.), 'the comprehensiveness of a voter roll - the proportion of eligible voters included in the list - ensures that electors are able to exercise their right to vote. The currency of the list - the extent to which information is updated - and its accuracy - the rate of error in names, addresses, gender, the date of birth'; these all guarantee electoral credibility/integrity. Wolf (2017, p.10) describes the importance of a credible voter register thus: 'A credible voter register confers legitimacy on the electoral process, helps prevent electoral fraud and ensures that every eligible voter can vote in an election and that they can do so only once'.

Prior to the deployment of BT in African elections, voter registers had been largely unreliable and problematic, raising serious questions about the quality of democracy in most countries on the continent. This development has to a large extent taken a more positive turn since the adoption of various BTs for voter registration, verification and authentication in Africa. For instance, in 2012 the Ghana Electoral Commission deleted about 130000 duplicate names from the voter register; and Côte d'Ivoire, in preparation for the 2009 elections, did exclude some duplicate names from its register. The introduction by the Malian government of the Numéro d'Identification Nationale (NINA) biometric card in 2013, was able to resolve challenges relating to establishing a reliable voter register (IDEA 2018). This eradicated duplications from the register and ensured compliance with the maximum number of 500 voters per polling station. 
In Cape Verde, BT has considerably reduced mistakes in voters' identification and improved the credibility of the voter register (IDEA 2018). Biometric technology has been able to achieve at least three goals in Africa. First is the conduct of cleaner, freer and fairer elections such as the 2015 general elections in Nigeria, where the deployment of smart card readers and the use of biometric voter registers were major catalysts for success. The second is the conduct of less contested and controversial elections and a fostering of a consensual environment among political parties, as demonstrated in Côte d'Ivoire and the Democratic Republic of the Congo. The third is that BT has been able to improve on electoral administration on the continent as evident in Côte d'Ivoire, Rwanda (Piccolino 2014) and Nigeria, among others. All of these indices not only improve electoral integrity, but are necessary pre-requisites for attaining sustainable democracy.

According to CODEO (2012), with specific reference to Ghana, the deployment of BT has improved electoral credibility and peace in the country. Citizens' trust in the electoral system has been greatly improved as $78 \%$ sampled Ghanaians agreed that BT has brought remarkable improvements in elections, while $87 \%$ aver that BT is a germane tool for improving credible and peaceful elections. Our argument is that democracy can only be sustained and the prospect of sustainable democracy improved under the foregoing circumstances. As such, BT for elections in Africa has not only improved voter registers and electoral integrity, but has also aided and continues to aid the peaceful consolidation of democracies across the continent. BT is thus creating the correct path for sustainable democracies across Africa as the e-democracy model establishes that manipulated elections and, by extension, limited electoral democracies can be reversed through the use of technology.

Furthermore, Golden et al. (2014) observe that with respect to the deployment of BT for voter identification and authentication in Ghana's 2012 elections, there was less multiple voting, out-of-district voting and ballot stuffing. This was the same experience in Nigeria when BTs such as PVC and SCR were introduced for the 2015 general elections. Such BTs were germane in curbing multiple voting and ballot stuffing and they fostered credible elections (Idowu 2018; Idowu \& Mimiko 2020a; Nwagwu 2016; Nwangwu 2015). Gelb and Diofasi (2016) and Olurode (2017) also observe that the deployment of BTs has reduced disputed election results and post-election violence in Africa. With respect to the Kenyan elections in 2013 and 2017, Kigwiru (n.d.) observes that BT prevented duplications and electoral fraud; ensured that only those who registered voted; and created optimism among electorates. Ayeni and Esan (2018) and Olurode (2017) also observed the same experience in Nigeria, including an improvement in the country's electoral integrity. 
Stronger and more efficient electoral institutions, a key ingredient for sustainable democracy, have also been largely achieved via the deployment of BTs in African elections. For instance, in adopting a biometric voter registration system, the Ghana EC was able to register over 14 million people within the space of 40 days. In 2012, in the build-up to the 2015 elections in Nigeria, the Independent National Electoral Commission (INEC) of Nigeria was able to register and produce PVCs for over 67 million citizens as against the mere 6 million the country's national e-ID programme was able to capture over the space of several years. Furthermore, for its 2015 elections, the National Electoral Commission of Tanzania was able to register over 23.2 million people in only four months in contrast to the only 2.4 million captured by the National ID Programme in over four years (Gelb \& Diofasi 2016). While it took Nigeria's INEC four months to manually register over 61 million voters in 2006, it took the commission only 21 days to register over 73 million voters in 2011 using BT (Ayeni \& Esan 2018). At the end of the 2015 elections in Nigeria, the Commonwealth Observer Group (2015) opined that: 'the introduction of biometric permanent voter cards is, in our view, a major factor in enhancing the integrity of the electoral process'.

Citing how much BT influenced electoral credibility, peaceful democratic alternation of power and improved the prospect of sustainable democracy in Nigeria's 2015 general elections, the then president elect, General Muhammadu Buhari averred:

But we thank God for technology - PVC and card reader. If not for this luck we had with technology... they [politicians] would have continued with what they used to do - go to their party offices or their sitting rooms, write the results, go to radio house and television house and announce the result and say whoever does not want the result should go to court.

(The Punch May 7, 2015)

This previous practice, as revealed in the foregoing excerpts, was without doubt inimical to the prospect of building and attaining sustainable democracy in any clime. BT was able to correct the anomalies to a very large extent. This is also corroborated by Olurode (2017, p. 802), who argued that electoral BTs in Africa have been able to enhance the secrecy of balloting; electorates have gained more autonomy and confidence; and electoral misconduct and impunity are being replaced by electoral best practices on the continent. Nevertheless, this is not without numerous challenges. For Olurode, BT has improved electoral credibility and 'strong' politicians can no longer write election results for themselves. All of these present a positive atmosphere and the prospect of sustainable democracy in Africa. 
It is pertinent to mention, however, that the deployment of BT for elections is not sufficient for a credible electoral process and the attainment of sustainable democracy, Rather, the independence and impartiality of EMBs and the presence of strong electoral institutions and active/vibrant civil societies are also critical for conducting credible elections (Idowu \& Mimiko 2020b). For instance, while South Africa is yet to deploy BT for any elections held since 1994, the country's electoral process has continued to improve tremendously. South Africa's electoral system could be ranked, arguably, above many other African states that have deployed BT, and could be pitted among the very best in terms of electoral credibility in Africa, despite the non-adoption of BT in its elections. It is therefore obvious that an efficient, independent and impartial EMB, strong electoral institutions and active/vibrant civil societies have been the sustenance of electoral credibility, thereby raising the prospect of sustainable democracy in that country.

\section{CHALLENGES AND LIMITATIONS OF BIOMETRIC TECHNOLOGIES IN AFRICAN ELECTIONS}

The deployment of BT in African elections has immensely impacted on the integrity, quality, credibility and transparency of elections on the continent, thereby showing signs of a movement towards sustainable democracy. Nonetheless, there still remains a myriad of challenges confronting its implementation. While these challenges are by no means peculiar to Africa, the continent seems to be the worst affected internationally. Obviously, the reason for this is not far-fetched, given the bad history of elections and democracy; the poor level of technological innovation; and the high level of poverty on the continent. The cost of deploying BT for elections also poses a serious challenge for Africa, where the level of poverty is relatively high. Given the largely impoverished conditions of states on the continent, it becomes doubtful whether the deployment of BT in African elections is sustainable (Gelb \& Diofasi 2016). Table 2 below presents the costs incurred in the deployment of BT for some selected African elections.

\section{Table 2: The Cost of BT incurred in Some Selected African Elections (in US Dollars)}

\begin{tabular}{|l|c|c|c|c|c|c|}
\hline Country & Year & $\begin{array}{c}\text { Registered } \\
\text { voters }\end{array}$ & Election cost & $\begin{array}{c}\text { Biometric } \\
\text { technology } \\
\text { cost }\end{array}$ & $\begin{array}{c}\text { Per voter } \\
\text { election } \\
\text { cost }\end{array}$ & $\begin{array}{c}\text { Per voter } \\
\text { biometric } \\
\text { cost }\end{array}$ \\
\hline Benin & 2011 & 4483000 & 51704000 & 12950000 & 14.1 & 2.7 \\
\hline Burkina Faso & 2012 & 4365000 & 58000000 & 23000000 & 13.3 & 5.3 \\
\hline Cameroon & 2013 & 5481226 & 39000000 & 15000000 & 7.1 & 2.7 \\
\hline
\end{tabular}




\begin{tabular}{|l|l|r|r|r|r|r|}
\hline Côte d'Ivoire & 2010 & 5780000 & 330000000 & 266000000 & 57.1 & 46.0 \\
\hline DRC & 2011 & 32000000 & 360000000 & 58000000 & 11.3 & 1.8 \\
\hline Ghana & 2012 & 14031793 & 124000000 & 70000000 & 8.8 & 5.4 \\
\hline Kenya & 2013 & 14350000 & 325000000 & 106200000 & 22.6 & 7.4 \\
\hline Mali & 2013 & 6800000 & 50000000 & 14300000 & 7.4 & 2.1 \\
\hline Nigeria & 2019 & 84004084 & 798305637 & $\begin{array}{r}\text { Not avail- } \\
\text { able }\end{array}$ & 9.5 & ----- \\
\hline Sierra Leone & 2012 & 2700000 & 25000000 & 10000000 & 9.3 & 3.7 \\
\hline Tanzania & 2015 & 23161440 & 120000000 & 720000000 & 5.2 & 3.1 \\
\hline Zambia & 2011 & 5167000 & 67600000 & 14700000 & 13.1 & 2.8 \\
\hline
\end{tabular}

Source: Adapted from Gelb and Diofasi (2016, p.8) and updated by the author

BT is not perfect, as there are continual incidents of failure and manipulation of the system. With respect to the 2015 deployment of SCR in Nigeria, Idowu (2018), Idowu and Mimiko (2020a), Yakubu (2017), Gelb and Diofasi (2016), and Nwangwu (2015) posit that there were incidents of card reader failure in capturing the fingerprints of some eligible voters. In fact, Nwangwu (2015) went further and averred that most of the polling officials were not aware that they needed to peel off the nylon film lids of the card readers. This lack of technological know-how raised the card reader failure rate up to $91 \%$ (EU 2016). It also affected the then incumbent president, whose fingerprints could not be authenticated by the card reader after several tries. Golden et al. (2014) observe that during the Ghanaian 2012 elections, there were many cases of biometric ID machine breakdown. This is corroborated by CODEO's (2013) report that there was a 19\% failure rate of biometric machines across polling stations in the 2012 Ghanaian elections. Election Observation Group (ELOG 2013) posits that during Kenya's 2013 elections, the electronic polling book either malfunctioned or completely failed at $55 \%$ of polling units across the country. Also, in Zambia, the fingerprints of over $10 \%$ of potential and eligible voters could not be captured by the biometric machine (Evrensel 2010), thereby disenfranchising a large number of voters.

The fact that BT is only able to address limited forms of electoral fraud also poses a challenge to its deployment for African elections. Hence, Cheeseman's (2015) argument that certain electoral irregularities like gerrymandering, voters' intimidation, and vote buying/selling, cannot be addressed by technologies. For instance, Rader (2016) observed flagrant multiple biometric registrations in Somaliland in 2008; while Hosein and Nyst (2014) observed over 700000 multiple registrations ahead of the 2011 DRC elections and the biometric technology did not significantly change the tradition of poorly conducted elections in the country (Debos 2016). The same was the case for the 2018 DRC elections, where BT could 
not stop the manipulation at ballot counting level (Wilson et al. 2019). Even though BT was successful for voter registration and verification in Uganda's 2016 elections, the election was grossly manipulated. As Cheeseman, Lynch and Willis (2018, p.1407) aptly described it, 'The election was marked by gross disparities, with the ruling National Resistance Movement (NRM) able to spend much more, while opposition leader, Kizza Besigye's efforts were hampered by his arrest and the intimidation of his supporters'.

Despite the use of biometric PVC and SCR for the 2015 and 2019 general elections in Nigeria, actions which raise concerns about their credibility were still rampant at various polling units across the country. These include electoral electoral violence, arson, under-age voting, vote buying and selling, burning of sensitive and non-sensitive electoral materials and the disruption of the electoral process. Various pre-election manipulations cannot be addressed by BT. These include the strategic disqualification of opposition candidates and the deliberate deprivation of voter registration at opposition strongholds as evident in the 2000 Côte d'Ivoire elections (Piccolino 2016) and across several other parts of Africa. Furthermore, unequal access of both incumbent and opposition to resources, and the intimidation of opposition leaders and their supporters as demonstrated in the Zimbabwean 2013 election (Freedom House 2014; Human Rights Watch 2014) and in many other parts of the continent, are obviously beyond the purview of BT. Gelb and Diofasi (2016) also add that electoral irregularities such as intentional miscounting of ballots, unaddressed legitimate electoral complaints, undue political influence, lack of political will to conduct clean elections, and poor implementation capacity often associated with African elections, are not within the confines of electoral frauds captured by the BT. Do Rosario and Muendane (2016) aver that during the 2014 biometric voter registration in Zimbabwe, the incumbent regime was able to manipulate the process in its favour. This was done by supressing registration in opposition areas by deploying inadequate equipment and undertrained registration/electoral teams to opposition strongholds.

Despite the huge budget allocated to BTs for Kenya's 2013 and 2017 elections, Kigwiru (n.d.) and Osei-Offul (2017) aver that the process still met with many deficiencies in terms of electoral malfeasance. Electronic transmission of results failed at some stages, and there the system was treated with suspicion for fear of being hacked. Such technological failures are bound to invoke suspicion and mistrust among electorates, candidates, political parties and observers alike. In Ghana and Nigeria's 2012 and 2015 elections respectively, voting was postponed to the next day in some polling units because of BT failures. Also, the proposed electronic transmission of results for Ghana's 2012 elections was abandoned, with the EC nursing fears that the system might have been hacked (Osei-Offul 2017). For the 2019 elections in Nigeria, the proposed electronic transmission of results 
was jettisoned, an act which was possibly caused by the lack of the technical know-how, or fear of the system being compromised, or both.

Furthermore, because Africa lacks the technological wherewithal and the funds to effectively deploy BT for elections, they are often contracted to foreign firms. This also extends to contracting foreign firms to make use of the BT to manage and clean voter registers. For instance, Somaliland's deployment in 2016 of iris scan, one of the most expensive BTs, was highly dependent on international donors to the tune of $€ 13.5$ million (Rader 2016). Kenya's deployment of BT in 2013 was also heavily dependent on the Canadian government (Ngetich \& Ayaga 2016); and the procurement in DRC of BT in preparation for the 2011 elections was highly dependent on a Belgian company, ZETES (Pourtier 2012). Gelb and Diofasi (2016) posit that these practices are capable of weakening Africa's ownership of the electoral process, including raising concerns about the independence of the process.

Cheeseman et al. (2018) have also identified the challenge of corruption as one besetting the deployment of BT for African elections. According to them, some of the support for electoral technologies may be for personal and selfish 'desire to open up fresh rent-seeking opportunities' (Cheeseman et al. 2018, p.1404), rather than the intention to improve electoral integrity. This may result in procurement challenges leading to quack companies getting contracts they are not capable of delivering (Do Rosario \& Muendane 2016); faulty procurement procedures and delays (Cheeseman et al. 2018); and corruption scandals such as those involving electoral process, as demonstrated in cases in Kenya in 2013 and 2017, and DRC in 2011 (Ohito 2016). Furthermore, implementation capacity for deploying BT for elections is largely lacking in Africa. Gelb and Diofasi (2016, p.17) describe this as 'pre-existing infrastructure: roads to deliver biometric kits, electricity to power card readers and scanners; reliable broadband or mobile networks to transmit data for de-duplication and to submit results, a robust data system to store, verify and tally the data received, trained staff to operate the equipment and perform troubleshooting if issues occur'. Osei-Offul (2017) holds the same perspective. Arguably, Africa lacks most of these capacities necessary for the efficient and effective deployment of electoral BT. These challenges continue to pose a threat to the prospect of attaining sustainable democracy via the deployment of BT in African elections.

While these challenges abound in BT deployment for African elections, it is pertinent to state that the deployment of BT has now meant that the mismanagement and rigging of elections in Africa began to happen more often in other areas in which BT is irrelevant. Some of these areas include vote counting and aggregation. This was the case in the DRC which had a technically proficient BT that supported elections up until the counting stages in 2011 and 2018 (Wilson 
et al. 2019). The same scenario is applicable in most other parts of Africa where elections are now being manipulated in the areas where BT is irrelevant.

\section{CONCLUSION}

The paper has been able to explore the link between the deployment of BT for African elections and the prospect of attaining sustainable democracy on the continent. There is no doubt that BT has contributed in no small measure to electoral integrity, voter confidence in the electoral process, and the inclusion of a larger percentage of citizens in the electoral roll. It has ensured that the credibility and transparency of African elections are improved, thereby increasing the prospect of sustainable democracy on the continent. BT has to a large extent helped to improve the electoral process on the continent. Also, as the e-democracy model posits, electoral BT has been useful in the democratisation process of Africa. It has thus improved democratic practice in no small measure and set most parts of the continent on the path to sustainable democracy.

Nonetheless, the deployment of BT for African elections still continues to face challenges and limitations. This is largely due to a number of factors, such as the fact that BT cannot address certain electoral frauds. Such frauds outside the purview of BT include voter intimidation, opposition intimidation, unequal access to resources by opposition and incumbents, and under-age voting. Others include violence, negative and undue political influence, and vote buying/selling. Given this, African politicians still continue to maximise the weak spots of BT to manipulate the process. Other challenges of BT in African elections include the high cost of BT machines, corruption, the lack of political will to conduct credible elections, lack of implementation capacity, and lack of technical know-how to professionally operate the BT machines.

Nevertheless, despite these numerous challenges, BT has improved the electoral process in African elections and it is creating the optimistic possibility of achieving sustainable democracy on the continent. To achieve this, however, African politicians must be patriotic enough to demonstrate the political will to conduct credible elections beyond the mere deployment of BT; Africa must invest more in the area of technological innovation. This is necessary to enable the continent to become self-sufficient in BT machines, thereby reducing the cost of deploying BT for elections on the continent, while also reducing the dependence level. Furthermore, African EMBs must give proper and adequate training to their electoral officers (permanent and ad hoc) before deploying them to the field. Strategies must be put in place by African EMBs to block the loopholes through which BT is still being manipulated. Beyond the deployment of BT for elections, the much-needed implementation capacity must be a top priority for African 
leaders and governments. This includes infrastructure - roads, electricity, reliable broadband, robust data system, and adequately trained personnel; strong electoral and democratic institutions; and active/vibrant civil societies. The man-made electoral frauds which BT cannot address can be dealt with when political leaders develop the political will and sincere commitment to conduct clean elections. Unless these issues are addressed head on, the prospect of attaining sustainable democracy in Africa may just fizzle out.

\section{--_-- REFERENCES}

ACE Electoral Knowledge Network [n.d.], 'Voter registration', ACE. Available at $<$ http://aceproject.org/ace-en/topics/vr>. [20 May 2019].

Arnold, W 2014, Elections and Democracy in Southern Africa, Foundation for European Progressive Studies, Brussels, Belgium.

Ayeni, TP \& Esan, AO 2018, 'The impact of ICT in the conduct of elections in Nigeria', American Journal of Computer Science and Information Technology, vol.1, no.6, pp. 1-6.

Bolle, R, Connell, J, Pankanti, S, Ratha, N \& Senior, A 2004, Guide to Biometrics, Springer, New York.

Cheeseman, N 2015, Democracy in Africa: How the rules of the game shape political developments, Cambridge University Press, Cambridge.

Cheeseman, N, Lynch, G \& Willis, J 2018, 'Digital dilemmas: The unintended consequences of election technology', Democratisation, vol.25, no.8, pp.13971418.

CODEO 2012, Final statement on the observation of the nationwide biometric voter registration (BVR) exercise, Coalition of Domestic Election Observers, Accra, Ghana.

CODEO 2013, Preliminary statement on Ghana's December 7 to 8 presidential and general elections, Coalition of Domestic Election Observers, Accra, Ghana. Available at $<$ http://www.codeoghana.org/images/CODEO_Preliminary_ Statement-2012_1.pdf>. [28 May 2019].

Commonwealth Observer Group 2015, 'Nigeria elections 2015: Interim statement', Foreign Commonwealth, 30 March. Available at $<\mathrm{http}: / / \mathrm{www}$. thecommonwealth.org/media/news/nigeria-elections-2015-interimstatement-commonwealth-observer-group $>$. [25 May 2019].

Debos, M 2016, 'Biometric in Chad: A new technologies and old electoral recipes', The Conversation, 27 April. Available at $<$ https://theconversation.com/biometrieau-tchad-nouvelles-technologies-et-vieilles-recettes-electorales-58394>. [23 May 2019]. 
Do Rosario, DM \& Muendane, EE 2016, 'Get registered? Yes, but vote? The hidden censor of voting materials during the 2014 elections in Mozambique', African Policy, vol.144, no.4, pp.73-94.

ELOG 2013, Elections Observation Group's observation of the voting process, Elections Observation Group, Nairobi, Kenya. Available at <http://www.elog.or.ke/ index.php/104-voting2013>. [25 May 2019].

Evrensel, A 2010, Voter Registration in Africa- A Comparative Analysis, Electoral Institute for the Sustainability of Democracy in Africa, Johannesburg.

Freedom House 2014, 'Zimbabwe: Freedom in the world 2014'. Available at <https://www.freedomhouse.org/report/freedom-world/2014/ zimbabwe\#VUknevIVhBe>. [20 May 2019].

Gelb, A \& Clark, J 2013, 'Identification for development: The biometrics revolution', Working Paper 315, Center for Global Development, New York.

Gelb, A \& Decker, C 2012, 'Cash at your fingertips: Biometric technology for transfers in developing countries', Review of Policy Research, vol.29, no.1, pp.91-117.

Gelb, A \& Diofasi, A 2016, 'Biometric elections in poor countries: Wasteful or a worthwhile investment?', Working Paper 435, Center for Global Development, Washington, DC.

Gemalto, 2019, 'Biometric technology: Gemalto's solutions and services'. Available at $<$ www.Gemalto.com/govt-site/PublishingImages/biometrics/what-isbiometrics.jpg >. [27 May 2019].

Genkey 2017, Delivering Biometric Elections, Genkey, Netherlands.

Golden, M, Kramon, E \& Ofosu, G 2014, 'Electoral fraud and biometric identification machine failure in a comparative democracy'. Available at $<$ www.goldenpolisci.ucla.edu/working progress/golden-kramon-ofosu.pdf $>$. [27 April 2019].

Hosein, G \& Nyst, C 2014, 'Aiding surveillance: An exploration of how development and humanitarian aid initiatives are enabling surveillance in developing countries', I \& N Working Papers, No1. International Development Research Centre (IDRC) and Centre for Recherches pour le Developpement International (CRDI). Available at $<$ https://www.idrc.ca/sites/default/files/ sp/Documents\%2DEN/WP2014-1-Aiding-Surveillance-web-Nov21.pdf $>$. [18 May 2019].

Human Rights Watch 2014, 'Zimbabwe: World report 2014'. Available at <http:// www.hrw.org/sites/default/files/wr2014_web_0.pdf>. [25 May 2019].

IDEA 2018, 'The use of new technologies in electoral processes', International Institute for Democracy and Electoral Assistance Workshop Report, Praia, Cabo Verde, 22-23 November 2017.

Idowu, HA 2017, 'Political parties and democratic consolidation: The Nigerian experience', Paper presented at the First Annual Conference of the Nigerian Political Science Association, South West Zone, Obafemi Awolowo University, March 8-9. 
Idowu, HA 2018, 'Election management and peaceful democratic transition in Ghana and Nigeria', Unpublished MSc. Thesis, Obafemi Awolowo University, Ile-Ife, Nigeria.

Idowu, HA \& Mimiko, NO 2020a, 'Election Management Systems and Peaceful Alternation of Power between Incumbent and Opposition Governments in Ghana and Nigeria', Politikon, vol.44, pp. 88-111.

Idowu, HA \& Mimiko, NO 2020b, 'Enabling factors for peaceful political power alternation and democratic consolidation in Ghana and Nigeria', Taiwan Journal of Democracy, vol.16, no.1, pp. 161-195.

Iizuka, M 2013, 'Innovation systems framework: Still useful in the new global context?' UNU-MERIT Working Papers 005, Maastricht Economic and Social Research Institute on Innovation and Technology (MERIT).

Kigwiru, VK 2019, 'The adoption of technology in the Kenyan electoral process: Lessons from the 2013 and 2017 presidential elections'. Available at <https:// ssrn.com/abstract=3383987>. [8 December 2019].

Lorimer, LT \& Lechner, DE 1995, The New Lexicon Webster's Dictionary of English Language, Lexicon Publishers, New York.

Maendeleo Policy Forum 2016, 'Deepening democracy: Election management and stability in Africa's divided societies', Report of the 6th Edition of the Maendeleo Policy Forum held in Nairobi, Kenya, 14 December.

Moynihan, DP 2004, 'Building secure elections: E-Voting, security and systems theory', Public Administration Review, vol.64, no.5, pp. 515-528.

Mumford, L 1964, 'Authoritarian and democratic technics', Technology and Culture, vol.5, no.1, pp.1-8.

Ngetich, J \& Ayaga, W 2016, 'IEBC officials on spot over 2013 poll', The Standard, 23 March. Available at <https://www.standardmedia.co.ke/article/2000195.798/ iebc-officials-on-spot-over-2013-poll>. [14 May 2019].

Nwagwu, EJ 2016, 'Information communication technology and administration of 2015 general elections in Nigeria', Mediterranean Journal of Social Sciences, vol.7, no.4, pp.303-316.

Nwangwu, C 2015, 'Biometric voting technology and the 2015 general elections in Nigeria', Paper presented to National Conference on the 2015 Elections Organised by the Electoral Institute, 27-28 July, University of Nigeria, Nsukka.

Ohito, D 2016, 'Why IEBC commissioners had to go', The Standard, 4 August. Available at $<$ http://www.standardmedia.co.ke/mobile/article/2000210774/why-iebccommissioners-had-t-go?pageNo=2>. [19 May 2019].

Olurode, L 2017, 'The slaughter's slab as a metaphor', Inaugural Lecture Delivered at the University of Lagos. March.

Olurode, L 2017, 'Technology and election conundrum: A case study of Nigeria', Sociology and Anthropology, vol.5, no.10, pp.799-811. 
Osei-Offul, R 2017, 'Solutions or problems? The increasing role of technology

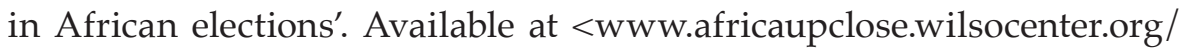
solutions-or-problems-the-increasing-role-of-technology-in-africanelections/> [28 April 2019].

Piccolino, G 2014, ‘Democracy by IDs and fingerprints? The politics of voter registration and voter registration reform in West Africa', European Consortium for Political Research (ECPR) General Conference, University of Glasgow, September 3-6.

Piccolino, G 2016, 'Infrastructural state capacity for democratisation? Voter registration and identification in Côte d'Ivoire and Ghana compared', Democratisation, vol.23, no.3, pp. 498-519.

Pourtier, R 2012, 'The 2011 elections in the DRC, between confusion and tampering', EchoGeo. Available at <http://journals.openedition.org/echogeo/13119> [02 April 2020].

Rader, M 2016, 'Recognition and controlled origin policies: Building Somaliland through its voter cards', African Policy, vol.144, pp. 51-72.

Robertson, L 2006, 'One man one vote: Trust between the electorate, the establishment and voting technology', The Journal of Technology Studies, vol.32, no.2, pp. 85-89.

Russell, M \& Zamfir, L 2018, 'Digital technology in elections: Efficiency versus credibility?' European Parliament Research Service PE 625. 178, September.

The Punch 2015, 7 May.

Wang, PSP \& Yanuschkevich, SN 2007, 'Biometric technologies and applications', Proceedings of the 25th IASTED, International Multi-Conference, Artificial Intelligence and Applications, p.226-231, Innsbruck, Austria, February 12-14.

Wilson, T, Blood, D \& Pilling D 2019, ‘Congo voting data reveal huge fraud in poll to replace Kabila: Ft analysis of two voting databases shows that Martin Fayulu won the presidential election', Financial Times, 15 January. Available at <https://www.ft.com/content/2b97f6e6-189d-11e9-b93e-f4351a53f1c3>. [30 January 2021].

Wolf, P 2017, Introducing Biometric Technology in Elections, International Institute for Democracy and Electoral Assistance, Stockholm, Sweden.

Yakubu, M 2017, The Use of Biometric Voter Authentication System: Experiences, Issues and Way Forward, ID4African and INEC, Windhoek, Namibia. 